\title{
Correction to: A Method of Motion-Estimation-Based H.264 Video Coding Using Optimal Search-Range
}

\author{
Narasak Boonthep ${ }^{1} \cdot$ Kosin Chamnongthai ${ }^{1}$
}

Published online: 12 February 2021

๑) Springer Science+Business Media, LLC, part of Springer Nature 2021

\section{Correction to: Wireless Personal Communications (2020) 115:2833-2850 https://doi.org/10.1007/s11277-019-06766-4}

The Acknowledgement section was missing in the original publication. The original article has been corrected.

Publisher's Note Springer Nature remains neutral with regard to jurisdictional claims in published maps and institutional affiliations.

The original article can be found online at https://doi.org/10.1007/s11277-019-06766-4.

Kosin Chamnongthai

kosin.cha@kmutt.ac.th

Narasak Boonthep

narasakb@gmail.com

1 Department of Electronic and Telecommunication Engineering, King Mongkut's University of Technology Thonburi, Bangkok, Thailand 